【論文】

\title{
スパッタ成膜 $\mathrm{a}-\mathrm{Si}: \mathrm{H}$ を用いたレーザー誘起 誘電泳動による光 MEMS 拡散センサーの開発 Development of Micro Optical Diffusion Sensor utilizing Laser-Induced Dielectrophoresis with Sputtered a-Si:H
}

\author{
鎌田慎*山田幹** 田口良広*** 長坂雄次***
}

Makoto Kamata, Kan Yamada, Yoshihiro Taguchi, and Yuji Nagasaka

\begin{abstract}
本研究では微量な生体試料の拡散係数を高速に測定する MEMS デバイスを開発している. 拡散現象 を高速に検知するため, 本測定法ではレーザー誘起誘電泳動を利用して前処理不要なマイクロスケー ル濃度分布形成を可能としている，レーザー誘起誘電泳動には励起光照射により導電率が上昇する光 導電膜が必要であり, 水素化アモルファスシリコンが用いられる. 今回, 反応性 RF マグネトロンス パッタ法により光導電膜を種々の条件で成膜し, 提案するデバイスへの適用性を評価した。評価結果 に基づき測定デバイスを作製し，拡散現象を検知した。これにより，スパッタ成膜 $\mathrm{a}-\mathrm{Si}: \mathrm{H}$ を用いた光 MEMS 拡散センサーの妥当性が確認されたので報告する.
\end{abstract}

In this study, micro optical diffusion sensor (MODS) is developed to measure the diffusion coefficient of biological sample such as protein with small sample volume in a short time. By utilizing the laser-induced dielectrophoresis (LIDEP), an additives-free and a high-speed sensing can be realized in the proposed method. The photoconductive layer is essential material for LIDEP, and the high-contrast photoconductivity change is required to form the concentration distribution of the biological sample using LIDEP. In this paper, a hydrogenated amorphous silicon (a-Si:H) is deposited as the photoconductive layer by a reactive RF magnetron sputtering method, which is a simple method compared with other technique such as a plasma-enhanced chemical vapor deposition. a-Si:H was deposited in several sputtering conditions and evaluated the applicability to the sensing device. A measurement device was fabricated, and the diffusion phenomenon of the lattice-shaped concentration distribution was detected by the device.

[Keywords: Diffusion coefficient, Laser-induced dielectrophoresis, MEMS, Photoconductive layer]

\section{1.はじめに}

タンパク質に代表される生体高分子における拡散係数測 定は，生体内で起こる物質移動現象を解明し，生体工学か ら医療・創薬まで幅広い研究分野へ寄与寸ると考えられる. 生体試料の拡散係数測定手法として, 動的光散乱法[1] や Taylor 法[2]，位相シフト干渉計[3,4] などが用いられ，高

* 慶應義塾大学大学院理工学研究科総合デザイン工学専攻, 干223-8522 横浜市港北区日吉 3-14-1.

School of Integrated Design Engineering, Keio University, 3-14-1 Hiyoshi, Yokohama 223-8522.

FAX: 045-566-1735 E-mail: kamata@naga.sd.keio.ac.jp

** 株式会社協同インターナショナル， †216-0033 川崎市宮前区 宮崎 2-10-9.

Kyodo International, Inc., 2-10-9, Miyazaki, Kawasaki 216-0033.

*** 慶應義塾大学理工学部システムデザイン工学科, †223-8522 横浜市港北区日吉 3-14-1.

Department of System Design Engineering, Keio University, 3-14-1 Hiyoshi, Yokohama 223-8522.

FAX: 045-566-1735 E-mail: tag@sd.keio.ac.jp
精度な測定を実現している.

一方で Terazima ら[5-7] は過渡回折格子(TG) 法を用い

て, ms オーダーで変化するタンパク質拡散係数の測定を 行っている. 試料の構造などを反映する拡散係数を高速に センシングし, $\mathrm{ms}$ オーダーで起こるタンパク質の構造変 化や分子の摇らぎを検知することで，生体分子が機能を発 現するメカニズムの解明に寄与している，また，TG 法な どを利用した拡散係数測定によって，薬剤一タンパク質間 やタンパク質同士の相互作用の高効率なバイオセンシング を達成している $[7,8]$. しかし, TG 法は励起光によって構 造変化や反応が誘起される物質に限定され，反応性がない 物質を用いる場合には前処理が必要である[7]. 生体試料は 周囲の温度や水素イオン濃度などの環境に影響を受けやす いため，短時間における環境変動を排除した測定が望まれ るが，広範な試料に適用可能な手法は測定に $\min \sim \mathrm{h}$ を要 するという難点を抱えている. 
本研究ではレーザー誘起誘電泳動 (laser-induced dielectrophoresis: LIDEP) を用いた光 MEMS 拡散センサー (micro optical diffusion sensor: MODS) の開発を行っており, これまでに提案手法の妥当性が示されている[9,10] . また， センサーの小型化に関する研究も行われている [11].

LIDEP は optoelectronic tweezers (OET) [12] を基にした微小 粒子操作技術である.試料の限定や修飾などを必要とせず, 印加電圧の周波数と励起光の照射パターンにより任意の濃 度分布を形成できることから主に生体試料の操作や分離に 用いられる。

LIDEP には励起光の照射により導電率が上昇する光導 電膜が必要不可欠であり, プラズマ化学気相成長(PECVD) 法により成膜された水素化アモルファスシリコン $(\mathrm{a}-\mathrm{Si}: \mathrm{H})$ が用いられてきた[9-11]. 本研究では, PECVD と比較して 安全かつ簡易な反応性 RF マグネトロンスパッタ法を用い た a-Si:H の成膜を提案する. 成膜温度や原料ガス混合比等 の成膜条件から導電率特性を容易に変更可能である提案手 法により LIDEP が誘起可能であれば，OET を用いた研究 に対しても多大に寄与すると考えられる. 本報では, 複数 の条件を用いて a-Si:H の成膜を行い, デバイス作製及び実 験的検討により拡散係数センシングへの適用可能性を評価 したので報告する.

\section{2．測定原理および測定装置}

\section{1 レーザー誘起誘電泳動}

本研究では拡散現象の高速検知を行うため, 試料溶液へ LIDEP を適用することで, Fig. 1 に示すようなマイクロス ケールの縞状濃度分布を形成する $[9,10]$ 。

濃度分布形成のための駆動力となる誘電泳動力 $\left(\mathbf{F}_{\mathrm{DEP}}\right)$ は非一様な電場 $(\mathbf{E})$ と, それにより粒子に生じる電気双極 子の相互作用によって誘起される. 誘電率 $\varepsilon_{\mathrm{m}}$ の溶媒中に ある半径 $a$ の粒子に働く誘電泳動力は以下の式で表され る.

$$
\mathbf{F}_{\mathrm{DEP}}=2 \pi \varepsilon_{\mathrm{m}} a^{3} \operatorname{Re}\left[K^{*}(\omega)\right] \nabla \mathbf{E}^{2}
$$

ここで, $K^{*}(\omega)$ は Clausius-Mossotti 関数と呼ばれる印加 電圧の角周波数 $\omega$ の関数であり, 溶媒, 溶質それぞれの複 素誘電率によって決定され， $-0.5<\operatorname{Re}\left[K^{*}(\omega)\right]<1$ の值をと る. 本測定法では $\operatorname{Re}\left[K^{*}(\omega)\right]>0$ となる条件を適用し, 二乗

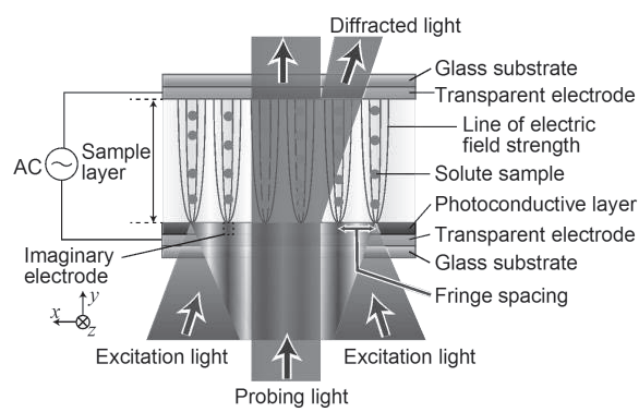

Fig. 1 Schematic image of measurement principle.

電界強度 $\left(\mathbf{E}^{2}\right)$ が高い方へ粒子を駆動する[9-12].

非一様な二乗電界強度分布を形成するためLIDEP では, 励起光の照射によって暗導電率 $\left(\sigma_{\mathrm{d}}\right)$ から明導電率 $\left(\sigma_{\mathrm{ph}}\right)$ 一 導電率が上昇する光導電膜を利用する. 本測定法では試料 層内に明瞭な濃度分布を形成する必要があり，駆動に十分 な誘電泳動力の誘起が必要である. そのため, 濃度分布形 成に十分な誘電泳動力を誘起可能な，高いコントラストの 導電率変化(i.e. $\left.\sigma_{\mathrm{ph}} / \sigma_{\mathrm{d}}>1\right)$ を有する光導電膜が必要とされ る。

\section{2 縞状濃度分布の形成および拡散現象の検知}

光導電膜に対して二光束干渉させた励起光を入射すると, 励起光の強度に応じて導電率が上昇するため, 励起光の干 渉縞に従って仮想電極が形成される．さらに，透明電極間 に交流電圧を印加すると試料層内に非一様な二乗電界強度 分布が形成され, 誘電泳動力により濃度振幅 $\Delta c$, 間隔 $\Lambda$ の 縞状濃度分布が形成される．濃度分布誘起を遮断すると， その後の濃度分布 $c(x, t)$ は,

$c(x, t)=\Delta c \exp \left(-\frac{t}{\tau_{\mathrm{D}}}\right) \cos \left(\frac{2 \pi x}{\Lambda}\right)+c_{0}$

となり, 縞状濃度分布は指数関数的に減衰し, 初期濃度 $c_{0}$ に収束する.このときの拡散時定数 $\tau_{\mathrm{D}}$ を用いると拡散係数 Dは,

$D=\frac{\Lambda^{2}}{\tau_{\mathrm{D}}(2 \pi)^{2}}$

と表される。

縞状濃度分布に観察光を照射すると，濃度分布により形 成される縞状屈折率分布が位相型回折格子の役割を果たし 回折光が生じる. 回折効率は屈折率振幅の 2 乗に比例する ため, 式(2) で表される拡散によって 1 次回折光の強度 $I_{1}$ 
は以下の式に従い減衰する.

$I_{1}(t) \propto \exp \left(-\frac{2 t}{\tau_{\mathrm{D}}}\right)$

1 次回折光強度の減衰を検知し, 算出した減衰時定数を式

(3) に代入することで拡散係数が算出される[9].

本測定法をタンパク質などの生体分子の拡散係数測定に 適用することを考えると，その拡散係数は $10^{-10} \mathrm{~m}^{2} / \mathrm{s}$ 程度 である[3] ことから $\Lambda=5 \mu \mathrm{m}$ に設定した場合， $\tau_{\mathrm{D}}$ は $\mathrm{ms}$ 才 ーダーとなり高速な検知が可能となる.

\section{3. 反応性 RF マグネトロンスパッタ法を}

\section{用いた光導電膜の成膜と評価}

\section{1 光導電膜成膜方法}

本研究では反応性 RF マグネトロンスパッタ法を用いた LIDEP 用 a-Si:H の成膜を提案する. 反応性 RF マグネトロ ンスパッタ法はターゲットとして $\mathrm{Si}$, 原料ガスとして $\mathrm{H}_{2}$ を混合した Ar ガスを用いることから, 成膜温度や圧力, スパッタ時の電力, 水素混合比などを変更することで, 光 導電性や光学的特性など膜質を調節しながら a-Si:H を平 易に成膜することが可能である.

本報では，提案する成膜手法の妥当性を検証するために Table 1 に示寸条件にて成膜を行った. 成膜時の圧力および $\mathrm{RF}$ 出力は RF マグネトロンスパッタ法で一般的に用いら れる值を設定し, 温度を室温(r.t.), $150{ }^{\circ} \mathrm{C}, 200{ }^{\circ} \mathrm{C}$ と変化 させて約 $1 \mu \mathrm{m}$ 成膜し, 評価した結果について報告する.

Fig. 2 に各温度でスライドガラス上に成膜したa-Si:H を示 す. 膜厚を触針式表面プロファイラーで測定したところ, それぞれ $0.91 \mu \mathrm{m}$ (r.t.), $1.00 \mu \mathrm{m}\left(150^{\circ} \mathrm{C}\right), 0.95 \mu \mathrm{m}\left(200^{\circ} \mathrm{C}\right)$ であった．色調に差があることから成膜温度により光学的 特性が異なることがわかる.

Table 1 Depositing condition.

\begin{tabular}{cccc}
\hline \hline Pressure & Power & Source gas & Temperature \\
\hline $1.4 \mathrm{~Pa}$ & $400 \mathrm{~W}$ & $\mathrm{Ar}+9 \% \mathrm{H}_{2}$ & r.t. $/ 150^{\circ} \mathrm{C} / 200^{\circ} \mathrm{C}$ \\
\hline \hline
\end{tabular}

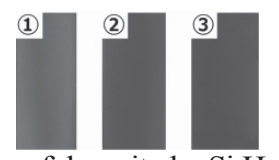

Fig. 2 Image of deposited a-Si:H on slide glass.

(1) r.t. (2) $150{ }^{\circ} \mathrm{C}$ (3) $200{ }^{\circ} \mathrm{C}$

\section{2 光学的特性および膜質の評価}

堆積した薄膜の構造特性を評価するために, レーザーラ マン分光光度計を用いた測定を行った. 結果を Fig. 3 に示 す. $480 \mathrm{~cm}^{-1}$ 近傍のピークはアモルファス構造に由来する. 膜中に微結晶シリコンや結晶シリコンが存在する場合 500 $\mathrm{cm}^{-1}, 518 \mathrm{~cm}^{-1}$ 近傍にもピークが現れるが[13], Fig. 3 から は $480 \mathrm{~cm}^{-1}$ 近傍のピークしか現れず，いずれの条件におい てもアモルファス膜が成膜されていることが確認された。

また, 紫外可視分光光度計を用いて a-Si:H の透過率を測 定した結果を Fig. 4 に示寸。測定原理の関係上，観察波長 を透過する必要があり, また, 明膫な導電率分布を形成す るためには励起波長に高い吸収性を持つ必要がある。本測 定法では観察光源として波長 $635 \mathrm{~nm}$, 二光束干渉させる励 起光源として $532 \mathrm{~nm}$ のレーザーを利用する. Fig. 4 より 成膜した光導電膜はいずれも観察波長で $50 \%$ 以上の透過 性を有しており，観察光透過性の条件を満たす。また，励 起波長について透過率および膜厚をもとに, 吸収係数 $\alpha$ を 算出したところ, Table 2 の結果が得られた. これより, 200 ${ }^{\circ} \mathrm{C}$ で成膜した光導電膜において, 最も大きな導電率変化が

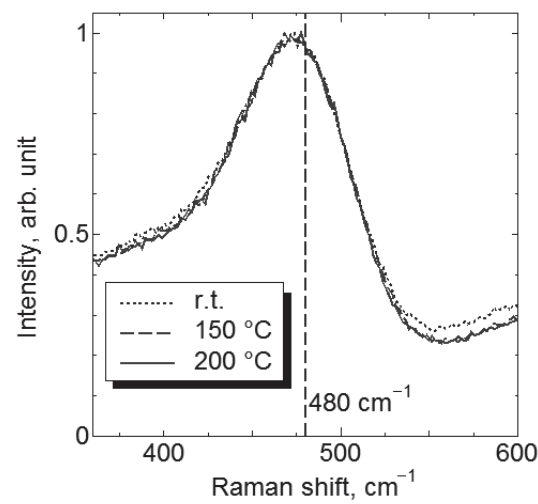

Fig. 3 Measurement result of Raman shift.

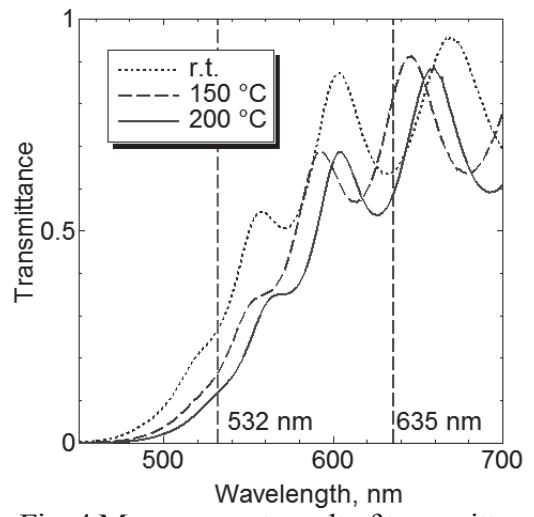

Fig. 4 Measurement result of transmittance. 
Table 2 Depositing temperature and absorption coefficient $\alpha$ (wavelength: $532 \mathrm{~nm}$ ).

\begin{tabular}{c|ccc}
\hline \hline Temperature & r.t. & $150{ }^{\circ} \mathrm{C}$ & $200^{\circ} \mathrm{C}$ \\
\hline$\alpha, \times 10^{-6} \mathrm{~m}^{-1}$ & 1.4 & 1.8 & 2.2 \\
\hline \hline
\end{tabular}

期待されることが分かった.

\section{3 光導電率の評価}

最も大きな導電率変化が期待される $200{ }^{\circ} \mathrm{C}$ で成膜した a-Si:H について, 光導電率を評価するため, スライドガラ スに成膜した a-Si:H の上面へ抵抗測定用の電極を形成し た. Fig. 5 に示寸ように励起に用いる波長 $532 \mathrm{~nm}$ のレー ザー光を測定用電極へ照射し, 励起光強度と抵抗值 $R$ の関 係を測定した. 電極幅 $w$, 電極間距離 $l$ および堆積した光 導電膜の厚み $d$ を用いて導電率 $\sigma$ は,

$\sigma=\frac{1}{R} \frac{l}{w \cdot d}$

\section{と表される.}

測定用電極を形成するにあたり，電極形状を設計した. その際, 測定部位で強度が一様とみなせるよう励起光直径 $(1.7 \mathrm{~mm})$ に比べて電極間距離が十分に小さくなるよう設 計した。電極形状を転写するためのステンシルマスクを作 製し，a-Si:H にステンシルマスクを密着させた状態で高真 空蒸着装置により $\mathrm{Au}$ を蒸着することで, 測定用電極を形 成した. Fig. 6 に実際に形成した電極の一例を示寸. 設計 值で電極幅は $800 \mu \mathrm{m}$, 電極間距離は $50 \mu \mathrm{m}$ であり, Fig. 6 より設計した通りに電極が形成されていることがわかる. 電極形成後, 導電性ペーストを用いて電極と高抵抗測定装 置を接続し，測定した.

光導電率の測定結果を Fig. 7 に示し, Ohta らが OET に

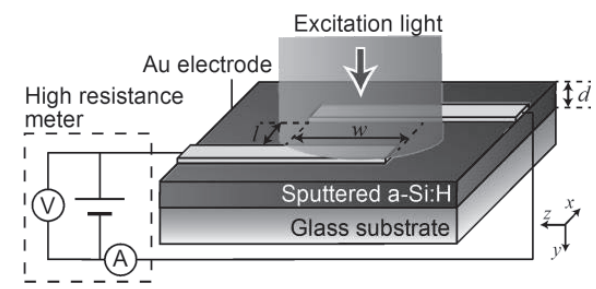

Fig. 5 Evaluation method of photoconductivity.

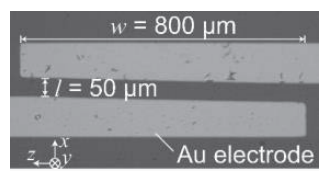

Fig. 6 Deposited Au electrode for evaluation of photoconductivity.

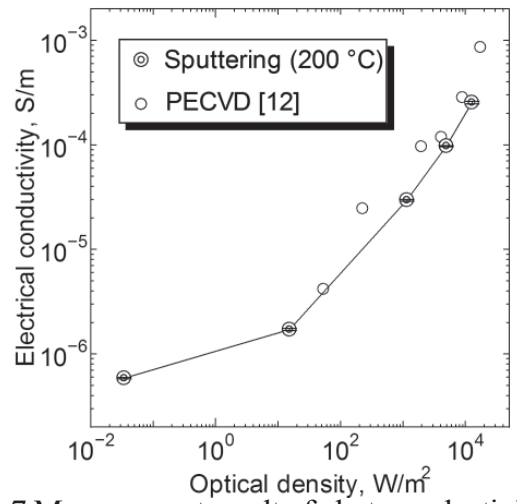

Fig. 7 Measurement result of photoconductivity.

適用している PECVD 法成膜 a-Si:H の測定結果[12] を併 せて示す．使用した高抵抗測定装置は $200 \mathrm{~T} \Omega$ の入力イン ピーダンスを有することから，式(5) より $\sigma>10^{-8} \mathrm{~S} / \mathrm{m}$ であ れば測定可能であり，結果はその範囲に収まっている，反 応性 RF マグネトロンスパッタ法により成膜したa-Si:H も 励起光強度の増加に伴い，導電率が上昇する傾向が見られ た．その入射光強度変化に対寸る導電率変化は PECVD 法 により成膜されたものと同程度の変化を示し，安全で簡易 な提案手法による LIDEP 誘起可能性が示唆された。 反応 性 RF マグネトロンスパッタ法により成膜した a-Si:H の本 測定法への適用妥当性を確認寸るため, 同成膜条件を用い て測定デバイスを作製した.

\section{4. スパッタ成膜デバイスにおける拡散現象検知}

\section{1 デバイスファブリケーション}

拡散係数測定デバイスの作製にあたって，まず合成石英 基板 $(0.5 \mathrm{~mm})$ 上に反応性 $\mathrm{RF}$ マグネトロンスパッ夕により 透明電極としてスズドープ酸化インジウム(ITO, 200nm) を成膜し,その上へ $200^{\circ} \mathrm{C}$ の条件を用いて $\mathrm{a}-\mathrm{Si}: \mathrm{H}(1 \mu \mathrm{m})$ を 成膜した。ささに，スピンコートにより厚膜用ネガ型フォ トレジスト SU-8 3025 を $40 \mu \mathrm{m}$ 成膜し, フォトリソグラフ イー技術を用いて流路形状をパターニングした．また，別 の合成石英基板にサンドブラスト加工により試料封入用の 貫通穴を作製し，ITO $(200 \mathrm{~nm})$ を同様に成膜した。各基板 をダイシングソーにより $15 \mathrm{~mm} \times 7.5 \mathrm{~mm}$ のチップに切り 分け, サーマルボンディング $\left(190{ }^{\circ} \mathrm{C}\right)$ でサンドウィッチ構 造を形成した．試料溶液を流路へ封入する前に，試料一流 路表面間の吸着を低減するために猪谷ら[10] と同様の表 


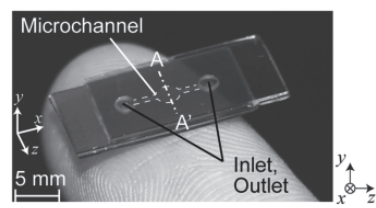

(a) Fabricated measurement device

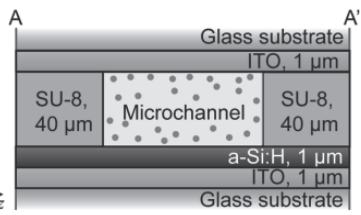

(b) Cross section of device

Fig. 8 Figure of fabricated device and schematic image of cross section.

面改質を施し，流路表面を親水性に改質した。作製した測 定デバイスおよびデバイスの構造断面を Fig. 8 に示す.

4. 2 拡散現象の検知

作製した誘電泳動セルを用いて, LIDEP による 1 次回折 光の検知および拡散に伴う強度の減衰検知を行った。 その 際の光学系を Fig. 9 に示す. 無偏光ビームスプリッター (NPBS1) で二分割された励起光は, 光導電膜上で交差し干 渉縞を形成する. 干渉縞間隔をビームプロファイラーで観 察したところ $\Lambda=9.5 \mu \mathrm{m}$ であった. 光導電膜にわずかに吸 収される観察光による不用な誘電泳動誘起を避けるため, ファンクションジェネレーター(FG1) とシャッターを用い て, 励起光の入射, 交流電圧印加(FG2) のタイミングに観 察光の入射タイミングが重ならないよう制御し, 実験した. 測定時の励起光の強度, ビーム径ならびに印加電圧と濃度 分布誘起時間を Table 3 に示す.

測定試料として，ポリスチレンビーズ水溶液 $(\varphi 500 \mathrm{~nm}$, $0.1 \mathrm{vol} \%)$ を用いた. 半径 $a$ の球状粒子の拡散係数は, 溶媒 の温度 $T$, 粘性率 $\eta$ およびボルツマン定数 $k_{\mathrm{B}}$ を用いて以下 の Stokes-Einstein の式により算出することができる.

$$
D_{\text {Theory }}=\frac{k_{\mathrm{B}} T}{6 \pi \eta a}
$$

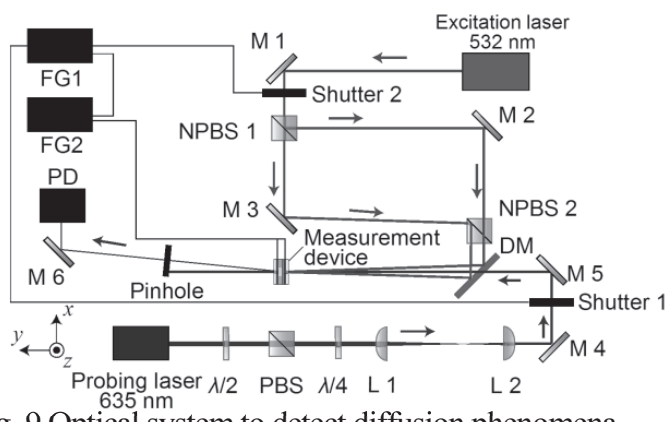

Fig. 9 Optical system to detect diffusion phenomena.

(DM: dichroic mirror, FG: function generator, L: lens, M: mirror, NPBS: non-polarized beam splitter, PBS: polarized beam splitter, PD: photo detector, $\lambda / 2$ : half-wave plate, $\lambda / 4$ : quarter-wave plate)

Table 3 Measurement condition.

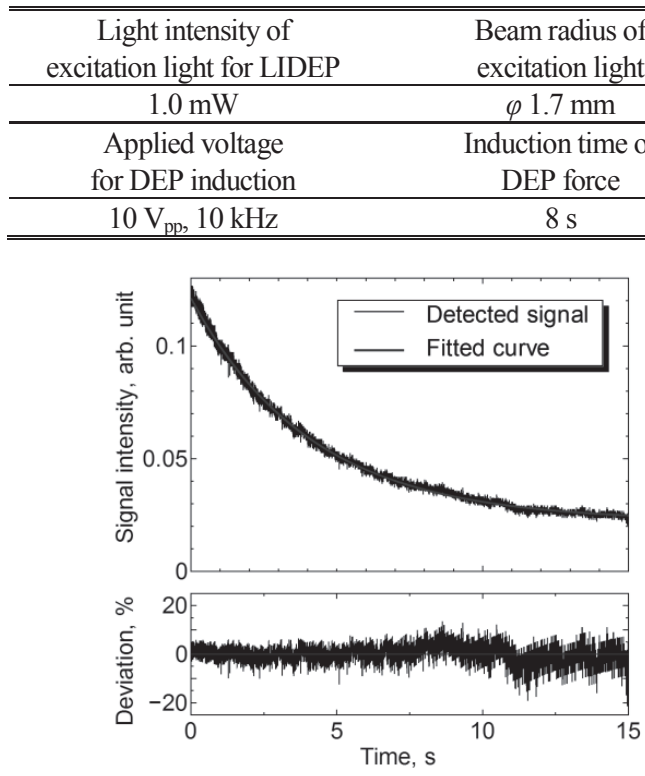

Fig. 10 Detected decay of intensity of the first order diffracted light.

試料の温度を $298 \mathrm{~K}$ として拡散係数を算出すると, $D_{\text {Theory }}=$ $9.7 \times 10^{-13} \mathrm{~m}^{2} / \mathrm{s}$ と求められる.

励起光の照射および交流電圧の印加により縞状濃度分布 を誘起し，観察光を照射したところ 1 次回折光の検知に成 功した. 濃度分布誘起を終了すると, 物質拡散に伴い Fig. 10 に示すような 1 次回折光が減衰する様子が検知された。こ の波形から減衰時定数はフィッティング解析により $\tau_{\mathrm{D}}=$ $8.2 \mathrm{~s}$ と算出され，Fig. 10 下に示した解析結果と検知波形 の差分から，良好にフィットしていることがわかる. 式(4) に干渉縞間隔 $\Lambda=9.5 \mu \mathrm{m}$ を代入することで, $D=3 \times 10^{-13}$ $\mathrm{m}^{2} / \mathrm{s}$ と算出され, 測定結果から算出される拡散係数は式(6) により算出される理論值とオーダーで一致した.

以上より，ノイズによる不確かさが大きいが，理論に即 した指数関数的な減衰挙動が検知され，スパッタ成膜 a-Si:H を用いた LIDEP による本測定手法の妥当性が示さ れた. 今後，本測定法を利用してタンパク質など拡散係数 が大きく, 減衰時定数が小さい試料を測定すれば，ms 才 ーダーの高速な測定が実現すると期待される.

\section{5. 結 論}

本報では LIDEP を用いた拡散係数測定デバイスの開発 
について述べた．以下に結論を示す。

1. LIDEP に必要不可欠な光導電膜について, 反応性 RF マグネトロンスパッタ法を用いた簡易な成膜手法を提 案し, 成膜および特性の評価を行い, 成膜温度 $200^{\circ} \mathrm{C}$ において PECVD 法成膜と同程度の性能が期待される a-Si:H 成膜に成功した.

2. 新規成膜手法により測定デバイスを作製し，ポリスチ レンビーズ水溶液を用いて縞状濃度分布を誘起し, 観 察光を照射したところ 1 次回折光および拡散による減 衰挙動が検知された，よって，新規手法により成膜し た a-Si:H が LIDEP に適用可能であることが示された.

3. LIDEP に適用可能な a-Si:H の成膜, 評価からデバイス 作製に至るまでの一連のプロトコルが確立された.

\section{[謝辞]}

本研究の一部は, 日本学術振興会科学研究費補助金基盤 研究(S)(No. 24226006), 挑戦的萌芽研究(No. 15K13890) の 支援を受けて実施された。 また，デバイスの作製にあたっ ては，4大学ナノ・マイクロファブリケーションコンソー シアムおよび川崎市ナノ・マイクロ産学共同研究開発補助 金の支援を受けた。

\section{NOMENCLATURE}

a : radius of particle, $\mathrm{m}$

c : concentration, $\mathrm{g} \cdot \mathrm{l}^{-1}$

d : thickness, $\mathrm{m}$

$D \quad$ : diffusion coefficient, $\mathrm{m}^{2} \cdot \mathrm{s}^{-1}$

E $\quad$ : electric field, $\mathrm{V} \cdot \mathrm{m}^{-1}$

$F_{\text {DEP }} \quad:$ dielectrophoretic force, $\mathrm{kg} \cdot \mathrm{m} \cdot \mathrm{s}^{-2}$

I : light intensity, W

$k_{\mathrm{B}} \quad:$ Boltzmann constant, $\mathrm{J} \cdot \mathrm{K}^{-1}$

$K \quad$ : Clausius-Mossotti function

$l \quad:$ length between electrodes, $\mathrm{m}$

$R \quad$ : resistance, $\Omega$

$T \quad$ : absolute temperature, $\mathrm{K}$

$w \quad$ : electrode width, $\mathrm{m}$

$\varepsilon \quad$ : permittivity, $\mathrm{F} \cdot \mathrm{m}^{-1}$

$\eta \quad$ : viscosity, $\mathrm{Pa} \cdot \mathrm{s}$

$\Lambda \quad$ : fringe spacing, $\mathrm{m}$

$\sigma \quad$ : electrical conductivity, $\mathrm{S} \cdot \mathrm{m}^{-1}$

$\tau_{\mathrm{D}} \quad$ : decay time constant, $\mathrm{s}$

$\omega \quad$ : angular frequency, $\mathrm{rad} \cdot \mathrm{s}^{-1}$

Subscript

d : dark

$\mathrm{m} \quad$ : surrounding medium

ph : photo

\section{参考文献}

[1] N. Kanzaki, T. Q. P. Uyeda, K. Onuma; "Intermolecular Interaction of Actin Revealed by a Dynamic Light Scattering Technique", J. Phys. Chem. B, 110 (2006) 2881-2887.

[2] A. Hawe, W. L. Hulse, W. Jiskoot, R. T. Forbes; "Taylor Dispersion Analysis Compared to Dynamic Light Scattering for the Size Analysis of Therapeutic Peptides and Proteins and Their Aggregates", Pharm. Res., 28 (2011) 2302-2310.

[3] J. F. Torres, A. Komiya, D. Henry, S. Maruyama; "Measurement of Soret and Fickian diffusion coefficients by orthogonal phase-shifting interferometry and its application to protein aqueous solutions", J. Chem. Phys., 139 (2013) 074203 .

[4] 小宮敦樹，円山重直，守谷修一;「タンパク質物質拡 散現象における広域緩衝液の影響評価」，熱物性， 24 (2010) 15-20.

[5] K. Kuroi, K. Okajima, M. Ikeuchi, S. Tokutomi, T. Kamiyama, M. Terazima; "Pressure-Sensitive Reaction Yield of the TePixD Blue-Light Sensor Protein", J. Phys. Chem. B, 119 (2015) 2897-2907.

[6] 寺嶋正秀；「摇らぎ・ダイナミクスと生体機能」寺嶋 正秀編 (2013) 159-169, 化学同人.

[7] J. S. Khan, Y. Imamoto, Y. Yamazaki, M. Kataoka, F. Tokunaga, M. Terazima; "A Biosensor in the Time Domain Based on the Diffusion Coefficient Measurement: Intermolecular Interaction of an Intermediate of Photoactive Yellow Protein", Anal. Chem., 77 (2005) 6625-6629.

[8] A. Kumar, V. M. Gorti, H. Shang, G. U. Lee, N. K. Yip, S. T. Wereley; "Optical Diffusometry Techniques and Applications in Biological Agent Detection", J. Fluids Eng.-Trans. ASME, 130 (2008) 111401.

[9] 猪谷恒一, 田口良広, 長坂雄次 ; 「レーザー誘起誘電 泳動を用いた小型拡散センサーに関する研究」, 日本機 械学会論文集 B 編， 77 (2011) 1567-1577.

[10] 猪谷恒一, 蛭子井明, 田口良広, 長坂雄次 ; 「レーザ 一誘起誘電泳動を用いた小型拡散センサーの開発」, 熱物性, 23 (2009) 197-202.

[11] T. Oka, K. Itani, Y. Taguchi, Y. Nagasaka; "Development of Interferometric Excitation Device for Micro Optical Diffusion Sensor Using Laser-Induced Dielectrophoresis", J. Microelectromech. Syst., 21 (2012) 324-330.

[12] A. T. Ohta, P.-Y. Chiou, H. L. Phan, S. W. Sherwood, J. M. Yang, A. N. K. Lau, H.-Y. Hsu, A. Jamshidi, M. C. Wu; "Optically Controlled Cell Discrimination and Trapping Using Optoelectronic Tweezers" IEEE J. Sel. Top. Quantum Electron., 13 (2007) 235-243.

[13] L. Houben, M. Luysberg, P. Hapke, R. Carius, F. Finger, H. Wagner, "Structural porperties of microcrystalline silicon in the transition from highly crystalline to amorphous grouth", Philos. Mag. A-Phys. Condens. Matter Struct. Defect Mech. Prop., 77 (1998) 1447-1460.

[Received Jun. 28, 2015, Accepted Dec. 9, 2015] 